\title{
The Impact of Family and Social Support during the First Six Months after Attempt for Smoking Cessation
}

\author{
Sigara Bırakmada Aile Desteğinin ve Sosyal Desteğin İlk Altı Aylık \\ Dönemdeki Etkisi
}

\author{
Bektaş Murat Yalçın*, 'Mustafa Ünal,
}

\begin{abstract}
Objective: The aim of the present study was to investigate the effect of family and social support on smoking cessation during the first six months after the cessation attempt. Methods: The files of 312 patients who were admitted to the Smoking Cessation Outpatient Clinic of Family Medicine Department, Ondokuz Mayıs University Faculty of Medicine between January 2011 and January 2012 were reviewed and their socio-demographic data, smoking characteristics, Fagerström Nicotine Dependence Test (FNDT) score and treatment methods were recorded. Participants were called in a five-minute structured interview and their quit rate was investigated. They were also evaluated for the support they received from the family and social environment during the cessation period with a ten-point Likeert Scale $(0=$ Never, $10=$ Excellent) Findings: Of the cases, $190(61 \%)$ were male and $122(39 \%)$ were female. While the mean FNBT score of the group was $5.1 \pm 1.7$, the package / year value was $22.3 \pm 18.7$. Forty four out of 209 participants $(21 \%)$ who were started medication (Varenicline or Bupropion) and 23 out of 127 participants (\%18\%) who were started Nicotine Replacement Therapy (NRT) had been smoking for six months. There was not a statistically significant difference between genders with regard to overall social and family support scores $($ male $=$ $41,3 \pm 15,3$, female $=44,4 \pm 16,0, \mathrm{t}=1,495, \mathrm{p}=0,136)$. According to a multivariate binary logistic regression model, overall social and family support score $(\mathrm{OR}=1,044)$, age $(\mathrm{OR}=-1,038)$, and presence of another smoker family member $(\mathrm{OR}=0,501)$ were found as independent factors on smoking cessation. Conclusion: Family and social support are important factors for both gender during making a decision for smoking cessation, during smoking cessation and after smoking cessation and detailed studies are needed.
\end{abstract}

Key words: Smoking, family support, social support, family, primary care

ÖZET

Amaç: Bu araştırmada sigara bırakma denemesine karar verme ve sonraki ilk altı aylık dönemde sigara bırakma üzerine aile ve sosyal çevreden alınan desteğin etkisinin araştırılması hedeflenmiştir. Araç ve Yöntem: Ondokuz Mayıs Üniversitesi Tıp Fakültesi Aile Hekimliği Sigara Bıraktırma Polikliniği’ne Ocak 2011-Ocak 2012 tarihleri arasında başvuran 312 kişinin dosyaları taranarak kişilerin sosyodemografik verileri, sigara kullanma özellikleri, Fagerstrom Nikotin Bağımlılık Testi (FNBT) skoru ve aldıkları tedavi yöntemleri not edilmiştir. $\mathrm{Bu}$ kişiler telefonla aranarak beş dakikalık yapılandırılmış bir görüşme gerçekleştirilmiş ve sigarayı bırakma oranları araştırılmıştır. Görüşmede ayrıca sigara bırakma aşamasında ve sigarayı bırakırken aileden ve sosyal çevreden aldıkları destek onlu bir Likert Skala ile değerlendirilmiştir ( $0=$ Hiç, 10=Mükemmel). Bulgular: Çalışmaya alınanların 190'1 (\% 61) erkek, 122'si (\%39) kadındı.

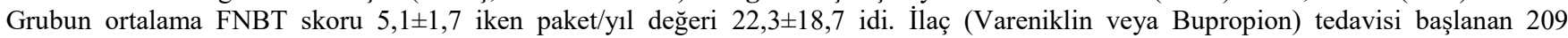
katılımcının 44'ü (\%21), Nikotin Replasman Tedavisi (NRT) başlanan 127 katılımcının 23'ü (\%18) altı aydır sigara içmiyordu $\left(\mathrm{x}^{2}=0,283\right.$, $\mathrm{p}=0,868)$. Her iki cinsiyetin aldığ 1 toplam sosyal destek ve aile desteği puanları birbirinden istatistiksel olarak anlamlı değildi (erkekler= $41,3 \pm 15,3$, kadınlar $=44,4 \pm 16,0, \mathrm{t}=1,495, \mathrm{p}=0,136)$. Multivariate binary logistic regression modeline göre toplam sosyal ve ailesel destek puanı $(\mathrm{OR}=1,044)$, yaş $(\mathrm{OR}=-1,038)$ ve sigara bağımlısının evinde başka birinin daha sigara içmemesi $(\mathrm{OR}=-0,501)$ sigara bırakma üzerinde bağımsız faktörler olarak bulunmuştur. Sonuç: Sigara bırakma kararı alma, bırakma esnasında ve bırakma sonrasında aile desteği ve sosyal destek her iki cinsiyet için önemli bir faktördür ve bu konuda detaylı araştırmalara ihtiyaç vardır.

Anahtar kelimeler: Sigara, aile desteği, sosyal destek, birinci basamak

Received / Geliş tarihi: 17.07.2018, Accepted / Kabul tarihi: 27.09.2018

${ }^{1}$ Ondokuz Mayıs Üniversitesi Üniversitesi Tıp Fakültesi Aile Hekimliği Anabilim Dalı

*Address for Correspondence / Yazışma Adresi: Bektaş Murat YALÇıN, Ondokuz Mayıs Üniversitesi Tıp Fakültesi Aile Hekimliği A.D.

Kurupelit/Samsun - TÜRKIYE, E-mail: myalcin@omu.edu.tr

Ünal M, Yalçın BM. Sigara Bırakmada Aile Desteğinin ve Sosyal Desteğin İlk Altı Aylık Dönemdeki Etkisi. TJFMPC, 2019;13(1): 52-59.

DOI: $10.21763 /$ tjfmpc.528022 


\section{GíRIŞ}

Sigara bağımlılığ sağlığı problemi haline gelmiştir. Türkiye'de 2012 yılında yapılan Küresel Yetişkin Tütün Araştırması verileri 15 yaş üzeri nüfusun \%27,4'ünün her gün sigara içtiğini göstermektedir. ${ }^{1} \mathrm{Bu}$ çalışmanın verilerine dayanarak ülkemizde yaklaşık 14 milyondan fazla kişinin aktif olarak sigara içtiği düşünülmektedir. 2016 yılında ülkemizde iç piyasada tüketilmek üzere yaklaşık 160 milyon dal (adet) sigara üretilmiştir. ${ }^{2}$ Son yıllarda ülkemizde sigara içen kişi sayısındaki artışta bir duraklama izlense de halen çok sayıda insan aktif olarak sigara içmektedir. ${ }^{3}$ Toplum bazında sigara içmeye karşı olumsuz bir etki 1996 yılında kabul edilen 4207 nolu yasa ile başlamıştır, Dumansız Hava Sahası hareketi, 171 Sigara Bırakma Hattı ve ücretsiz ilaç kampanyaları ile bu etki pekişmiştir. ${ }^{4} \mathrm{Bu}$ yaklaşımların etkinlikleri akademik açıdan tartışmaya değerdir. Sağlık sistemlerinin sigara ile mücadelesinde birinci basamak sağllk hizmetlerini dikkate almadan hazırlanan planların gerçekçi başarı şansı bulunmamaktadır. Bu bağlamda birinci basamak hekimliğinde sigara ile mücadele için üç önemli strateji geliştirilmelidir. Bunlar sırası ile hiç sigara içmemişlerin durumunun korunması, halen içenlerin bırakmasının sağlanması ve bırakmayı deneyip başaranların durumlarının devam ettirilmesi şeklinde sıralanabilir. $\mathrm{Bu}$ stratejiler içinde en önemlisi şüphesiz sigara ile hiç tanışmamış bir nesil yaratmaktır. Bunun yanında halen sigara içmekte olanlara verilecek sağlık hizmetinin de iyi koordine edilmesi gerekmektedir. Sigara içen kişilerin sigarayı bırakmaya karar vermesini ve bunu sürdürmesini davranışsal açıdan açıklamak için en sıklıkla transteoretik model kullanılmaktadır. ${ }^{5} \mathrm{Bu}$ modele göre sigara içen bir kişi beş farklı evrede değerlendirilir. İlk evre bırakmanın düşünülmediği evredir (precontemplation). $\mathrm{Bu}$ evrede birey sigaray bırakmayı düşünmez hatta sağlığı için zararlı olduğu fikrine sahip değildir. Bırakmanın düşünülmesi (contemplation) evresinde birey henüz bırakmaya karar vermemiştir fakat birakmayı düşünür ve sigaranın sağlığa zararları, bırakma yolları hakkında bilgi edinmeye çalışır. Bırakma hazırlığının yapılması (preparation) evresinde birey sigarayı bırakmasına yardım edecek bir plan ve strateji geliştirmiştir. Bırakmanın denenmesi (action) evresinde ise birey sigarayı bırakmış ancak denemenin üzerinden altı ay geçmemiştir. Bırakmanın sürdürülmesi (maintenance) evresinde ise denemenin üzerinden altı ay geçmiştir.

Şimdiye kadar sigara bırakma üzerine etkili olabilecek birçok faktör araştırılmıştır. Bireysel faktörler arasında kişinin yaşam tarzı değişikliği için motivasyonu, genetik nikotin duyarlılığı, öfke ve stres kontrol becerileri sayılabilir. ${ }^{6}$ Tedaviye ait faktörler arasında ise bireyselleştirilmiş psikolojik ve medikal tedavinin uygunluğu, tedaviyi uygulayan danışmanın tecrübesi ve düzenli takip dikkat çekicidir. ${ }^{7}$ Birçok yazar sigarayı bırakma evresinde aile ve sosyal çevre faktörleri konusuna dikkat çekmiştir. ${ }^{8-9} \mathrm{Bu}$ yazarların transteoretik modele göre vardıkları ortak nokta aile desteğinin ve sosyal desteğinin sigara birakma eylemi üzerinde doğrudan etkili olduğudur. $\mathrm{Bu}$ destek sistemlerinin bireylere farklı şekilde yardım ettiği ileri sürülmektedir. ${ }^{10}$ İlk olarak bireyin aldığı bu ailesel ve sosyal desteğin yaşamını olumsuz etkileyen bazı faktörleri elimine ederek veya etkisini azaltarak kişiye yardımcı olduğu öne sürülmüştür. Bireyin karşılaştığı olumsuz yaşam deneyimleri karşısında alacağı maddi veya psikolojik desteğin bireyin iç direnç mekanizmaları üzerinde pekiştirici bir etkisi olduğu ifade edilmektedir. Bu durumun da kişinin sağlık durumu üzerinde doğrudan olumlu etki yarattığ düşünülmektedir. Ayrıca bireyin ailesi ve/veya sosyal çevresinin kişinin yaşam tarzı değişikliği döneminde karşılaştığı fiziksel, psikolojik veya çevresel gerginleştiricilerin etkilerine karşı kısmen veya tümüyle tampon görevi yaparak bireylere yardım ettiği diğer bir ön görüdür. ${ }^{8-10}$

Bütün bu ipuçlarına rağmen sosyal çevre ve ailesel desteğin sigara bırakma üzerindeki etkileri konusundaki çalışmalar dünyada ve ülkemizde oldukça sınırlıdır. ${ }^{11}$ Aile ve sosyal desteğin sigara bırakma üzerinde hipotetik olarak özellikle transteoretik modelin bırakmanın denenmesi aşamasına (bırakma eyleminde altı ay sonrasına) kadarki dönemde başarı için kritik olduğu düşünülebilir. $\mathrm{Bu}$ noktadan hareketle çalışmamızın amacı sigara bırakma polikliniğimize gelen hastalarda aile ve sosyal çevre desteğinin bireyin, sigarayı bırakmaya karar vermesinde ve sigara birakma esnasındaki etkisinin araştırılmasıdır.

\section{ARAÇ ve YÖNTEMLER}

\section{Araştırmanın Tasarımı}

Bu çalışma Samsun ilinde Ocak 2011 ve Ocak 2012 tarihleri arasında Ondokuz Mayıs Üniversitesi Tıp Fakültesi (OMUTF) Sigara Bıraktırma Polikliniği'ne başvuran kişilerin başvurularından alt1 ay sonrasinda sigarayı birakma durumları ile aldıkları aile ve sosyal desteğin etkisi arasındaki ilişkiyi araştırmak amacıyla yapılmış prospektif, analitik, kontrollü ve tanımlayıcı tipte bir araştırmadır. Çalışma evrenini OMUTF Sigara Bıraktırma Polikliniği'ne gelen ve birer hafta ara ile en az iki motivasyonel görüşme gerçekleştiren, bilinen başka bir madde bağımlılı̆̆ olmayan 1587 gönüllü sigara bağımlısı oluşturmuştur. OMU Tıp Fakültesi Aile Hekimliği Sigara Bıraktırma 
Polikliniği'ne başvuran her hastaya özel bir dosya çıkarılmakta ve rutinde standart olarak en fazla üç ay süre ile takip edilmektedir. Her hasta en az bir kez sigara bırakma gününde telefonla aranmaktadır ancak belirli durumlarda klinik gereklilik üzere daha sik aranan hastalar da mevcuttur. İlk başvuru esnasında hastalardan sosyodemografik özellikleri (cinsiyet, yaş, eğitim yılı, medeni durum vb.) ve geçmiş dönemdeki sağlı durumları (hastalık, kullanılan ilaçlar vb.) ile ilgili anamnez alınmaktadır. Sigara kullanım öyküsü (Fagerström Nikotin Bağımlılık Testi [FNBT], paket/yıl, evde başka sigara içen kişinin varlığı, aldığı tedavinin tipi ve süresi vb) her hastada bire bir sorgulanmakta ve dosyaya kaydedilmektedir ve takip sürecinde aldıkları tedavilerin özellikleri (tedavi süresi, yan etkiler, relaps vb.) yine bu dosyalara kaydedilmektedir.

Çalışma evrenini oluşturan vakaların dosyaları incelendikten sonra polikliniğe ilk başvuruları esnasında 18 yaşından büyük ve 65 yaşından küçük, en az bir yıldır düzenli sigara içen, dosya bilgileri tam olan (demografik özellikler, anamnez, sigara bağımlılığ 1 parametreleri ve aldığı tedavi) 348 katılımc1\%21,9) tespit edilmiştir. Bu katılımcılar polikliniğimize ilk başvuru tarihlerinden altı ay sonra telefonla tekrar aranmış ve görüşülen 319'u $(\% 19,6)$ çalışma örneklemini oluşturmuştur. Telefonla ulaşılan ancak verdikleri bilgilerin çelişkili olduğu düşünülen 7 katılımcının (\%2) bilgileri çalışma dışı bırakılmıştır. Telefonla ulaşılan katılımcılara ortalama beş dakika süren yapılandırılmış bir telefon görüşmesi gerçekleştirilmiştir. Bu görüşmeler aynı araştırmacı tarafından gerçekleştirilmiştir. Çalışmanın amacı her katılımcıya anlatıldıktan sonra sözlü onamları alınmıştır. Telefonla ulaşılan katılımcılara sigara kullanma durumları sorulmuştur. Alınan cevaplara göre katılımcılar "hiç bırakmayanlar"(tedavi başlangıcından sonra bir aydan daha kısa süre içinde tekrar sigaraya başlayıp halen sigara içenler), "tekrar başlayanlar"(başlanan tedavi ile en az bir ay kesintisiz olarak sigara içmeyi bırakıp daha sonra tekrar başlayanlar ,telefon görüşmesinde halen sigara içtiğini belirtenler) ve "sigara içmeyi bırakanlar"'(tedavileri ile bağlantılı olarak belirlenen tarihten bu güne dek hiç sigara içmemiş olanlar) olmak üzere üç gruba ayrılmıştır.. Katılımcılara sırasıyla aşağıdaki sorular yöneltilmiş ve her bir soruya 1 (Hiç) ile 10 (Mükemmel) arasında bir rakamla cevap vermeleri istenmiştir.

Sigara birakma kararı alırken ailenizden ne kadar destek aldınız?

Sigara bırakma kararı alırken sosyal çevrenizden ne kadar destek aldınız?

Sigarayı bırakırken ilk dönemde (ilk dört hafta) ailenizden ne kadar destek aldınız?
Sigarayı birakırken ilk dönemde (ilk dört hafta) sosyal çevrenizden ne kadar destek aldınız?

Sigarasız dönemin sürdürülmesinde (ilk altı ay) ailenizden ne kadar destek aldınız?

Sigarasız dönemin sürdürülmesinde (ilk altı ay) sosyal çevrenizden ne kadar destek aldınız?

Daha sonra çalışmaya katılan bireylerin bu alt1 soruya verdikleri cevaplar tek tek değerlenmiştir. Her bir katılımcı için tüm destek skorları (sigara bırakma kararı, bırakma ve bu durumun sürdürülmesi için aile ve sosyal çevrenin destek puanlarının toplamı) aritmetik olarak toplanmış ve her katılımcı için tek bir sosyal destek puanı hesaplanmıştır. Elde edilen veriler kaydedilip farklı değişkenlerle ilişkileri incelenmiştir.

\section{Fagerström Nikotin Bağımlılık Testi (FNBT) ve Paket/Yl}

Nikotin bağımlılığını ve özellikle şiddetini değerlendirmek amacıyla geliştirilen birkaç ölçek bulunmaktadır. Bunlardan rutinde en çok tercih edileni Fagerström testi olup daha sonra bu testten Fagerström Tolerans Testi ve bağımlılık testi (FNBT) geliştirilmiştir. ${ }^{12} \mathrm{Bu}$ ölçek yardımıyla klinisyenler sigara içen hastalarını değerlendirebilecekleri gibi kişiler kendi kendilerini de değerlendirebilir. Altı sorudan oluşan bu anketten 0 ile 10 arasında bir puan alınabilir. Kişinin testten aldığı puan arttıkça fiziksel bağımlılığın arttığı düşünülür.

Paket/y1l ise tüm dünyada sigara araştırmalarında kişinin şimdiye kadar içtiği toplam sigara miktarını değerlendiren, dolayısıyla maruz kalınan toplam sigara dumanı yoğunluğu konusunda fikir veren bir ölçüttür. Kişinin sigara içtiği yıllar tek tek değerlendirilerek her yıl günde kaç paket sigara içtiği sorgulanır.

\section{İstatistiksel Yöntemler}

Araştırmada kullanılan veriler SPSS (Version V.12) paket programına yüklenmiştir. Veri analizinde korelasyon, ki-kare, ANOVA testleri kullanılmıştır. Sigara bırakma üzerindeki etkili olan faktörleri araştırmak için bir Multivariate Binary Logistic Regression Modeli oluşturulmuştur. Modelin bağımlı değişkenleri sigarayı bırakmak veya bırakmamak olarak kabul edilmiştir. Bırakmışlar grubuna ilk başvuru gününden altı ay sonrasında hala sigara içmeyen bireyler dâhil edilirken, bırakmamışlar grubunu sigara içmeye ara vermemiş veya bir süre ara verip yeniden başlamış kişilerden oluşmuştur. $\mathrm{Bu}$ açıdan sigara bırakma konusunda etkili olabilecek çeşitli bağımsız değişkenler araştırılmıştır. Bağımsız değişkenler olarak hastanın yaşı, cinsiyeti, FNBT skoru, paket/yıl değeri, aldı̆̆ toplam ailesel ve sosyal destek puanı, evde 
kendisinden başka herhangi birinin sigara içiyor oluşu ve sigara bırakmak için kendisine uygulanan farklı tedavi yöntemleri kabul edilmiştir. Bu bağlamda katılımcıların aldıkları tedaviler (Nikotin Replasman Tedavisi [NRT], Bupropion ve Vareniklin) ayrı parametreler olarak kabul edilmiştir. İstatistiksel anlamlılık düzeyi olarak $\mathrm{p}<0,05$ seçilmiştir.

\section{Etik İzin}

Çalışma için gerekli etik izin OMU Tıp Fakültesi etik kurulundan alınmıştır.

\section{BULGULAR}

Çalışmaya alınan vakaların demografik özellikleri, sigara kullanımına ait özellikleri ve tedavi yöntemlerini içeren veriler Tablo 1'de gösterilmiştir. İlk başvurudan altı ay sonra katılımcıların \%39,4'ü (n=123) sigarayı bırakmıştı, \%31,2'si içiyordu (n=97), \%29,4'ü $(n=92)$ ise sigaraya yeniden başlamıştı. İlaç (Vareniklin veya Bupropion) tedavisi başlanan 209 katılımcının 44'ü (\%21), Nikotin Replasman Tedavisi (NRT) başlanan 127 vakanın 23'ü (\%18) altı aydır sigara içmiyordu $\left(\mathrm{x}^{2}=0,283, \mathrm{p}=0,868\right)$. Başvuru esnasında her iki cinsiyette FNBT (Erkekler; $\mathrm{F}=2,741$, $\mathrm{p}=0,214$, Kadınlar; $\mathrm{F}=1,741, \mathrm{p}=0,174$ ) ve paket/yıl skorlar1 ile sigara birakma durumu arasinda (sigarayı bırakan, bir süre bırakan ve bırakmayan) istatistiksel olarak anlamlı bir ilişki saptanmamıştır (Erkekler; $\mathrm{F}=0,217, \mathrm{p}=0,117$, Kadınlar; $\mathrm{F}=0,974$, $\mathrm{p}=0,201$ ).

Cinsiyete göre ailenin ve sosyal çevrenin desteğinin sigara bırakma kararı, sigara bırakılması ve sürdürülmesindeki etkisini sorgulayan sorulara verilen cevapların ortalamaları ve bunların birbirleri ile karşılaştırılması Tablo 2'de gösterilmiştir. Çalışmaya katılanların toplam aile ve sosyal destek puanları incelendiğinde erkeklerin ortalama $41,3 \pm 15,3$ puan, kadınların ise $44,4 \pm 16,0$ puan aldıkları izlenmiştir. Her iki cinsiyete ait toplam puanlar arasında istatistiksel olarak anlamlı fark yoktu $(t=1,495, \quad p=0,136)$. Sigara birakma durumuna göre değerlendirildiğinde sigarayı bırakmış olan bireylerin almış olduğu toplam destek puanı $(48,5 \pm 15,6)$, sigarayı bir ara bırakmış olanlardan $(39,8 \pm 14,9)$ ve hiç bırakamamışlardan $(39,1 \pm 14,6)$ daha yüksekti $(F=9,460, p<0,001)$.

Sigara birakma üzerinde etkili olabilecek değişkenleri inceleyen Multivariate Binary Logistic Regression Modeli Tablo 3'te sunulmuştur. Bu modele göre $\% 95$ güven aralığında bireyin aldığ 1 toplam sosyal ve ailesel destek puan $(\mathrm{OR}=1,044$, alt=1,021, üst $=1,067)$, yaş $(\mathrm{OR}=1,038$, alt $=1,000$, üst $=1,076$ ) ve evde başka birinin daha sigara içiyor oluşu $(\mathrm{OR}=0,511$, alt $=0,269$, üst $=0,968)$ sigara bırakma üzerinde bağımsız etkili değişkenler olarak bulunmuştur.

\section{TARTIŞMA}

Araştırmamızın sonuçlarımıza göre her iki cinsiyetteki katılımcıların sigara bırakma kararı almasinda, sigara birakmada ve bunun sürdürülmesinde aileden aldıkları destek puanlarının ortalamaları arasında anlamlı bir fark saptanamadı. Sosyal destek açısından baktığımızda ise her üç aşamada da kadınlar erkeklerden daha fazla oranda arkadaşlarından destek aldıklarını belirtmişlerdir. $\mathrm{Bu}$ sonuçlar ilk başta yanıltıcı olabilir. Aile destek puanları arasında her iki cinsiyette bir fark izlenmemesi her iki cinsiyetteki katılımcıların ailelerinden sigara ile ilgili sorgulanan üç aşamada da çok yoğun destek görmüş olmalarından kaynaklanmıştır. Her iki cinsiyette araştırılan üç farklı aile destek puanı için (sigara bırakma kararının alınmasında, sigara bırakmada ve bunun sürdürülmesi) ortalamas1 8 puanın altında olan yoktu (Tablo 2). Bu sonuçlar her iki cinsiyetteki sigara bağımlılarının ailelerinden sigara bırakmaları için ciddi destek almakta olduklarını göstermekte idi. Ancak sosyal çevre desteği söz konusu olduğunda her iki cinsiyetteki bireyler, kendi ailelerinde aldıkları ile kıyaslandığında sosyal çevrelerinden aldıkları desteğin daha düşük bir düzeyde olduğunu belirtmektedirler. Ayrıca erkekler, kadınlarla kıyaslandığında her üç sosyal destek puanından (sigara bırakma kararının alınmasında, sigara bırakmada ve bunun sürdürülmesi) daha düşük skor almışlardır. Bu veriye dayanarak erkeklerin kendi sosyal çevrelerinde gördükleri destek seviyesini düşük olarak değerlendirdikleri ileri sürülebilir. Tüm aile ve sosyal çevre destek düzeyleri belirlenirken sübjektif değerlendirme ölçütleri kullanılmıştır. Dolayısıyla kişilerin aldıkları desteğin yeterli olduğu yönündeki bireysel algıları sigara bırakma başarısı için çok önemli bir faktör olarak izlenmektedir.

Genel literatürde sigara bırakma üzerinde aile ve arkadaşların olumlu veya olumsuz etkileri üzerinde oldukça farklı sonuçlar izlenmektedir. Esasen sosyal çevre ile karşılaştırıldığında ailenin sigara bırakma konusunda vereceği desteğin niteliği konusunda ciddi farklar bulunmaktadır. Kişi vaktinin büyük bölümünü dışarıda geçiriyorsa veya evde sigara içmemeye özen gösteriyorsa sosyal destek, tam tersi bir durum söz konusu ise aile desteği öne geçmektedir. Aile ve sosyal destek modelleri farklı kültürlerde farklı mekanizmalar ile etkileşim göstermekte olabilir. Birbirinden farklı Ortadoğu, Akdeniz veya Anglosakson kültürlerinde bu mekanizmalar birbirlerinden oldukça ayrı 
yöntemleri kullanıyor olabilirler. Örneğin, Bowes ve ark. ${ }^{13}$ herhangi bir eşle yaşayanların, bir eşle yaşamayanlara göre daha fazla oranda sigarayı bıraktığını bildirmişlerdir. Ancak bu çalışmada partnerlerinde sigara içip içmediği konusunda herhangi bir bilgi verilmediği gibi eşlerin nasıl motivasyon sağladığ $\breve{1}_{1}$ ile ilgili bir bilgi de yoktur.

\begin{tabular}{|c|c|c|c|}
\hline Değişken & Erkek $190(\% 61,7)$ & Kadın $122(\% 39)$ & \\
\hline Yaş (yıl) & $38,4 \pm 12,1$ & $41,7 \pm 10,3$ & $\mathrm{t}=1,716, \mathrm{p}=0,008^{*}$ \\
\hline Ĕgitim yılı (yıl) & $8,4 \pm 1,8$ & $6,2 \pm 2,1$ & $\mathrm{t}=3,024, \mathrm{p}<0,001^{*}$ \\
\hline $\begin{array}{l}\text { Medeni durum } \\
\text { Evli } \\
\text { Bekâr } \\
\text { Dul/Boşanmış }\end{array}$ & $\begin{array}{l}101 \% 53 \\
61 \% 32 \\
28 \% 25\end{array}$ & $\begin{array}{l}63, \% 51 \\
23, \% 20 \\
36, \% 29\end{array}$ & $\chi^{2}=13,766, \mathrm{p}<0,001^{\dagger}$ \\
\hline Fagerström Nikotin Bağımlılık Testi & $6,0 \pm 2,2$ & $5,6 \pm 2,1$ & $\mathrm{t}=1.1877, \mathrm{p}=0,074^{*}$ \\
\hline Paket/yıl (Ort.) & $28,8 \pm 20,6$ & $17,6 \pm 14,8$ & $\mathrm{t}=4,752, \mathrm{p}<0,001^{*}$ \\
\hline Yaş ile paket/yıl korelasyonu & $\mathrm{r}=0,762$ & $\mathrm{r}=0,574$ & $\mathrm{p}<0,001^{\ddagger}$ \\
\hline $\begin{array}{l}\text { Alınan Tedavi Şekli } \\
\text { Nikotin replasman tedavisi (NRT) } \\
\text { Bupropion } \\
\text { Vareniklin }\end{array}$ & $\begin{array}{l}99, \% 52 \\
50, \% 26 \\
41 \% 22\end{array}$ & $\begin{array}{l}66, \% 54 \\
27, \% 22 \\
29 \% 24\end{array}$ & $\begin{array}{l}\chi^{2}=1,257 \\
\mathrm{p}=0,456^{\dagger}\end{array}$ \\
\hline
\end{tabular}

\begin{tabular}{|c|c|c|c|}
\hline Sorular & Erkek & Kadın & $\mathrm{t}, \mathrm{P}$ \\
\hline $\begin{array}{l}\text { Sigara bırakma kararı alırken ailenizden ne kadar destek } \\
\text { aldınız? }\end{array}$ & $8,7 \pm 1,9$ & $8,1 \pm 2,9$ & $\begin{array}{l}\mathrm{t}=0,758 \\
\mathrm{p}=0,243^{*}\end{array}$ \\
\hline $\begin{array}{l}\text { Sigara bırakma kararı alırken sosyal çevrenizden ne kadar } \\
\text { destek aldınız? }\end{array}$ & $4,7 \pm 3,5$ & $5,7 \pm 3,5$ & $\begin{array}{l}\mathrm{t}=2,304 \\
\mathrm{p}=0,028^{*}\end{array}$ \\
\hline Sigarayı bırakırken ailenizden ne kadar destek aldınız? & $8,2 \pm 2,2$ & $8,2 \pm 3,0$ & $\begin{array}{l}\mathrm{t}=0,364 \\
\mathrm{p}=0,284 *\end{array}$ \\
\hline $\begin{array}{l}\text { Sigara birakırken sosyal çevrenizden ne kadar destek } \\
\text { aldınız? }\end{array}$ & $4,3 \pm 3,9$ & $6,0 \pm 3,8$ & $\begin{array}{l}\mathrm{t}=2,141 \\
\mathrm{p}=0,025^{*}\end{array}$ \\
\hline $\begin{array}{l}\text { Sigarayı bıraktıktan sonra ailenizden ne kadar destek } \\
\text { aldınız? }\end{array}$ & $8,4 \pm 2,5$ & $8,1 \pm 3,8$ & $\begin{array}{l}\mathrm{t}=0,953 \\
\mathrm{p}=0,587 *\end{array}$ \\
\hline $\begin{array}{l}\text { Sigarayı biraktıktan sonra sosyal çevrenizden ne kadar } \\
\text { destek aldınız? }\end{array}$ & $5,1 \pm 3,7$ & $6,1 \pm 3,4$ & $\begin{array}{l}\mathrm{t}=1,448 \\
\mathrm{p}=0,025^{*}\end{array}$ \\
\hline
\end{tabular}

Tablo 3. Sigara bırakma üzerinde etkili olabilecek değişkenleri inceleyen Multivariate Binary Logistic Regression Modeli

\begin{tabular}{|c|c|c|c|c|c|c|c|c|c|}
\hline \multirow{2}{*}{\multicolumn{2}{|c|}{ 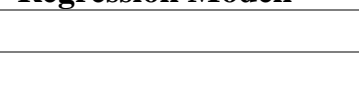 }} & \multirow[t]{2}{*}{ B } & \multirow[t]{2}{*}{ S.E. } & \multirow[t]{2}{*}{ Wald } & \multirow[t]{2}{*}{ df } & \multirow[t]{2}{*}{ Sig. } & \multirow[t]{2}{*}{$\operatorname{Exp}(B)$} & \multicolumn{2}{|c|}{ 95,0\% C.I.for $\mathrm{EXP}(\mathrm{B})$} \\
\hline & & & & & & & & Alt & Üst \\
\hline \multirow{10}{*}{$\begin{array}{l}\text { Step } \\
1 \text { (a) }\end{array}$} & Yaş & ,037 & ,019 & 3,877 & 1 & 039 & 1,038 & 1,000 & 1,076 \\
\hline & FNBT* &,- 121 & 073 & 2,711 & 1 &, 100 & ,886 & ,768 & 1,023 \\
\hline & $\begin{array}{l}\text { Evde Sigara } \\
\text { İçilmesi }(1)^{* *}\end{array}$ &,- 672 & ,326 & 4,236 & 1 & 040 & ,511 & 269 & ,968 \\
\hline & Paket/Y1l &,- 026 & ,016 & 2,523 & 1 &, 112 & 974 & ,944 & 1,006 \\
\hline & Tedavi (1) $\ddagger$ & & & ,982 & 2 & 612 & & & \\
\hline & Tedavi (2) & ,048 & ,355 & ,018 & 1 & 893 & 1,049 &, 523 & 2,104 \\
\hline & Tedavi (3) &,- 356 & ,411 & ,748 & 1 & ,387 & ,701 & ,313 & 1,569 \\
\hline & Destek Puan $\dagger$ & ,043 &, 011 & 14,694 & 1 &, 000 & 1,044 & 1,021 & 1,067 \\
\hline & Cinsiyet(1) &, 145 & ,345 &, 178 & 1 & 673 & 1,157 &, 588 & 2,274 \\
\hline & Constant & $-2,726$ & ,945 & 8,327 & 1 & ,004 & ,065 & & \\
\hline
\end{tabular}

a Değişkenler: Yaş, FNBT, Evde Sigara İçilmesi, Paket/Yıl, Kullanılan Tedavi, Cinsiyet 
Kısaltmalar ve açıklamalar;

*FNBT: Fagerstrom Nikotin Bağımlılık Testi

**Evde Sigara İçilmesi: Bağımlığın evinde kendisinden başka birisinin sigara içmesi

$\$$ Tedavi: Farklı tedavi yöntemi tercih edilen hastalar (Tedavi 1; Nikotin replasman tedavisi, Tedavi 2; Bupropion, Tedavi 3; Vareniklin)

$\dagger$ Destek Puan: Bireyin aldığı aile ve sosyal destek puanlarının toplamı

Eşlerin, sigara içen eşlerini/partnerlerini sigarayı bırakmaları yönünde motive etmeleri ile ilgili iki hipotez öne sürülmüştür. ${ }^{14}$ İlk hipotezde eşler, partnerlerinin sigara dumanından aşırı rahatsızlık duyup kendi sağlıkları için ciddi endişe duydukları öne sürülürken ikinci hipotez ise sigaraya bağlı risklerinden dolayı kendi eşlerinin sağlığ konusunda kaygılı olmalarıdır. ${ }^{14} \mathrm{Bu}$ iki hipotezi destekler nitelikteki bilgi 1996 yılında ABD'de Minnesota şehrinde yapılan bir çalışmada izlenmektedir. Buna göre sigara bırakmada ilk başarı oranları eşin destekleyici davranışları ile ilişskili iken, uzun dönemde bırakmadaki düşük başarı oranlarının eşin sigara bırakmaya dair kötü davranışları ile ilişkili olduğu görülmüştür. ${ }^{15} \mathrm{Bu}$ çalışmada eşler sigara dumanına bağlı olarak kendilerinin ve eşlerinin sağlığından ciddi olarak endişelenmekte idiler.

Cohen ve Lichtenstein' $1 n^{10}$ çalışmasında sigarayı birakanlar bir ay sonra arandığında partnerlerinin (eş, yakın arkadaş, aile üyelerinden birisi vb.) sigara bırakmaları ile ilgili sergiledikleri olumlu ve olumsuz geri bildirimleri alınmıştır. Bu çalışmanın sonucuna göre katılımcıların eşlerinden aldıkları olumlu geri bildirim puanları olumsuz geri bildirim puanlarından daha fazla idi. Kadınlar, erkeklere kıyasla anlamlı olarak daha fazla olumlu geri bildirim aldıklarını bildirmişlerdir $(\mathrm{t}=2,95$, $\mathrm{p}=0,004)$. Bu çalışmada ilk, üçüncü ve altıncı aylardaki sigara bırakma oranları ile bildirilen olumlu aile desteği ve sosyal destek arasında belirgin korelasyon izlenmiştir. Mermelstein ve ark. ${ }^{15}$ yaptıkları bir başka çalışmada sigara bırakma girişimlerini teşvik eden eşlerle yaşayan kişilerin ilk, üçüncü ve altıncı aydaki sigara bırakma oranlarının bir eşle yaşamayan kişilerden daha fazla olduğu gösterilmiştir. Olumsuz davranışların ise eşlerin sigara bırakma başarısı oranlarını etkilemediği görülmüştür. 2001 yılında sigara bırakmada sosyal desteğin önemini araştıran ilk meta analizde çalışmaların bir kısmında sosyal desteğin sigara bırakma oranının arttırdığ1 bulunurken (kontrol grubunun altı aylık sigara bırakma oranı $0-\% 64$, müdahale grubunun sigara bırakma oranı $0-\% 88,2$ ), kimi çalışmalarda ise sosyal destek alan ile almayan gruplar arasında sigara bırakma oranları açısından fark olmadığı bulunmuştur. ${ }^{16}$ Aynı yazarlar tarafından 2012 yılında yayınlanan bir başka meta analizde ise şimdiye kadar aile ve sosyal desteğin sigara bırakma üzerinde olan etkisinin araştırıldığı toplam 57 randomize kontrollü çalışma incelenmiştir. ${ }^{17}$ Araştırma ölçütlerine uyan 13 çalışmanın (>2000 vaka) sadece bir tanesinde aile ve sosyal desteğin sigara bırakma üzerinde anlamlı etkisi olduğu gösterilebilmiştir. İlginç olan nokta ise bu çalışmalarda cinsiyetin destek üzerindeki farklı etkisinin derinlemesine araştırılmamış olmasıdır. Hangi cinsiyetin sigara birakma konusunda eşine daha olumlu veya olumsuz destek verdiği araştırılmaya değer bir konu olarak görülmektedir.

Çalışmamızda oluşturulan nihai regresyon modelinde kişinin aldığı toplam sosyal destek miktarının yanında bağımlının yaşının ve yaşanan evde başka birinin sigara içmesinin sigara bırakması üzerinde etkili olan bağımsız risk faktörleri olduğu izlenmektedir. Bunun yanında ilginç olarak uygulanan tedavilerin başarı üzerinde ilk altı aylık sürede birbirlerinden anlamlı fark1 olmadığı izlenmektedir. Literatürde değişik medikal tedavi alternatiflerinin (NRT, vareniklin ve bupropion) birbirlerinden farklı başarı oranlarına sahip olduğu yönünde kuvvetli kanitlar mevcuttur. Yapilan meta-analizlere göre sigara birakma girişimden sonraki ilk yılda göreceli başarı şansı plasebo ile karşılaştırıldığında NRT'de 1,6 (\%95 güven aralığında, 1,5 ile 1,7), bupropion'da 1,6 (\%95 güven aralığında, 1,5 ile 1,8$)$ ve vareniklin'de 2,3 (\%95 güven aralığında, 2,0 ile 2,6) kez artmaktadır ${ }^{18-20}$. Çalışmamızda ortaya çıkan sonuç hem hastalarımızın sosyo-ekonomik özelliklerin hem de polikliniğimizde izlenen hasta takip sistemi ile açıklanabilir. Normalde polikliniğimize başvuran bir sigara bağımlısı üç aylık bir süre boyunca takip edilmektedir. Telefon konsültasyonları hariç böyle bir kişi ile ilk ay içinde dört kez ve sonraki aylarda da dört kez olmak üzere en az sekiz kez (ort.15 dak.) görüşme yapılmaktadır. Bu takip sayısı oldukça yoğun bir programdır ve hasta motivasyonunu artıran bir faktör olabilir. Uzun zaman içinde aynı ilaç tedavisi uygulanan hasta gruplarındaki başarı yüzdelerinin değişik çalışmalarda farklı olması, bazı yazarlarca bu tedavilerin motivasyonel görüşme ve diğer psikososyal destek programları ile desteklenmesi ile oluştuğunu belirtmişlerdir ${ }^{21-22}$. $\mathrm{Bu}$ durum aynı zamanda farklı ilaç kullanan kişiler için de geçerli olabilir. Bu tip motivasyonu arttırıcı ve psikososyal destek sistemlerini güçlendirici yaklaşımların sigara bırakmanın başarı şansını $\operatorname{arttırdığ~} \breve{g}_{1}$ bilinmektedir. Çalışmamızda ayrıca altı aylık bir sürede farklı ilaç grupları ile yüksek bir sigara bırakma oranı sağlandığı izlenmektedir. Bu sonucun anlaşılması için unutulmaması gereken ilk nokta polikliniğimize başvuran kişilerin sigara bırakmak için çok istekli olmasıdır. Bu yüksek sigara bırakma oranları yine sağlık sistemine ulaşılabilirliğin kolaylığı, aynı hekimle tedavinin sürdürülmesi, sık poliklinik izlemleri ve uygun motivasyonel ve psikososyal yaklaşımlarla açıklanabilir ${ }^{6}$. 
Sonuçlarımıza göre evde sigara dumanı ile karşılaşılmasının sigara bırakma deneyimi üzerine oldukça olumsuz bir etkisi olduğu izlenmektedir. Nikotin bilindiği üzere çok güçlü bir nöropsikolojik uyarıcıdır. Özellikle sigara bırakma denemesinin yapıldığı dönemde pasif olarak sigara dumanı ile karşılaşan kişilerde başarı şansının düştüğü bilinmektedir ${ }^{23}$. Bu etki hem solunan havadaki nikotinin bağımlı üzerinde yarattığı kimyasal etkiye hem de diğer psikolojik faktörlere bağlanılmaktadır ${ }^{24}$. Sigara bırakma denemesi yapan kişilerde sadece sigara içildiğinin görülmesi bile sigara içme isteğini çok güçlü bir şekilde tetiklemektedir. $\mathrm{Bu}$ nedenle sigarayı birakmayı planlayan kişinin evinde sigara içen diğer bireylerin de sigara bırakmaları için motivasyonlarının arttırılması başarı şansını arttırmak için mantıklı bir strateji olarak izlenmektedir.

Regresyon modelimize göre yaş arttıkça sigara bırakma başarısının arttığı izlenmiştir. Bazı çalışmalarda gençlerde sigara kullanımı ile eğitim düzeyi arasında ters ilişki saptanmıştır ${ }^{25}$. Genç bireylerin sigara bırakma başarısının düşük olması birkaç faktörle açıklanmaya çalışılmıştır ${ }^{26}$. Genç bireyler sigara için gerekli maddi kaynağ sağlamadıkları ve fiziksel olarak kendilerini kötü hissettikleri zaman sigara birakma konusunda daha motive olmaktadırlar. Sigara bağımlısı gençler özellikle sigara yokluğunda stres ve anksiyete ile nasıl baş edebileceklerini bilmediklerini belirtmektedirler. İleri yaşlarda ise uzun süre sigara kullanılmaya bağlı riskler konusundaki endişeler artmakta ve/veya bazı sağlık problemleri ile karşılaşılmaktadır. Bu nedenle daha yaşlı bireyler sigara birakma konusunda daha motive olabilirler.

Çalışmamızın oldukça güçlü yönleri olsa da konunun doğasından kaynaklanan bazı yetersizlikleri olabilir. Öncelikle bu çalışma ülkemizde konu ile ilgili ilk çalışmadır. Hastaların ilk altı aylık verilerinin takibi için oldukça detaylı ve titiz bir veri araştırma evresine sahiptir. Başlangıçta çalışmaya dâhil edilmesi planlanan 348 vakanın 29'una telefonla ulaşılamamıştır $(\% 10,4)$. Elimizde olmayan faktörlerden meydana gelen bu kayıp veri oranı yüksektir ve sonuçlarımızı etkileyebilir. Bir başka eleştiri vaka gruplarının oluşturulması ile ortaya getirilebilir. Vakaların sigara bırakma durumları telefonla belirlenmiştir. Hastaların telefonda sigara bırakma ifadelerinin sübjektif olabileceği konusunda eleştiri getirilebilir ama telefon konsültasyonu aracılığı ile yapılan çalışmalarda bu kaçınılmaz bir sonuçtur. Bu nedenle hastalarla telefon konsültasyonu yapılırken görüşülen yedi vakanın (\%2) verdiği bilgiler değişik sebeplerle çelişkili bulunmuş ve çıkarılmıştır. Bunun yanında bireylerdeki sigara bırakma üzerine olan aile etkisini ve sosyal etkiyi izole etmek oldukça güçtür. Konu ile ilgili ülkemizde tanımlanmış, geçerlilik ve güvenirlik testleri yapışmış bir anket bulunmamaktadır. Bu nedenle çalışmamızda katılımcıların kendi görüşlerini içeren bir Likert skala uygulanmıştır. Katılımcıların sosyal destek ve aile desteği ile ilgili değerlendirmelerinin bu nedenle sübjektif olacağ 1 öngörülebilir.

\section{SONUÇ}

Araştırmamız sigarayı bırakmak isteyen kişilerin aldığı aile desteği ve sosyal destek ve sigara bırakma oranları arasında bir ilişki olduğunu göstermiştir. $\mathrm{Bu}$ ilişki bırakma kararının verilmesi, sigara birakma ve bunun sürdürülmesinde cinsiyetten bağımsızdır. Ülkemiz kültüründe aile desteğinin ve sosyal desteğin nasıl artırılıp sigara bırakmada etkin kullanılacağı konusu araştırılmaya değerdir. Sigara bırakma danışmanlığı esnasında bu etkinin iyi kullanılması sigara içen kişilerde tedavi başarısını artırabilir. Konu ile ilgili daha detaylı çalışmalara ihtiyaç vardır.

\section{KAYNAKLAR}

1. GATS-Global adult tobacco survey. Comparison Fact Sheet Turkey, 2008 and 2012.

http://www.who.int/tobacco/surveillance/

survey/gats/gats Turkey 2008v2012 comparison fact sheet.pdf, Erişim tarihi: 10 Nisan 2018).

2. Tütün ve Alkol Dairesi başkanlığı, Tütün istatistikleri. http://www.tapdk.gov.tr/tr/piyasaduzenlemeleri/tutun-mamulleri-piyasasi/tutunmamulleri-istatistikleri.aspx, (Son erişim tarihi=11/07/2018).

3. The Tobacco Atlas; Turkey. https://tobaccoatlas.org/country/turkey/ (Son erişim tarihi=11/07/2018)

4. Bilir N. Türkiye'de Tütün Kontrolünün Öyküsü. 1. Bask1.Ankara: Ankara Ofset; 2017.s.30-39.

5. Prochaska JO, DiClemente CC. Transtheoretical therapy toward a more integrative model of change. Psychotherapy: Theory, Research, Practice, 1982; 19, 276-288.

6. Yalcin BM et al. Effects of an anger management and stress control program on smoking cessation: a randomized controlled trial. J Am Board Fam Med. 2014 ;27(5):64560.

7. Kahler et al. Positive psychotherapy for smoking cessation: Treatment development, feasibility and prelimanary results. J. Posit. Psychol. 2014; 9(1):19-29.

8. Mermelstein R, Cohen S, Lichtenstein E, Baer JS, Kamarck T. Social support and smoking cessation and maintenance. J Consult Clin Psychol. 1986; 54:447-453. 
9. Park EW, Tudiver F, Schultz JK, Campbell T. Does enhancing partner support and interaction improve smoking cessation? A meta-analysis. Ann Fam Med. 2004; 2:170-174.

10. Cohen S, Lichtenstein E. Partner behaviors that support quitting smoking. J Consult Clin Psychol. 1990; 58:304-309.

11. Yalçın BM, Unal M. The mid-term effect of grandchildren and children motivation to quit rates of smokers. J. Exp. Clin. Med., 2017; 34(1):73-77.

12. Heatherton TF, Kozlowski LT, Frecker RC, Fagerström KO. The Fagerström Test for Nicotine Dependence: a revision of the Fagerström Tolerance Questionnaire. $\mathrm{Br} \mathrm{J}$ Addict. 1991;86(9):1119-27.

13. Bowes L, Chollet A., Fombonne E, Melchior M. (). Psychological, social and familial factors associated with tobacco cessation among young adults. Europ Addic Res, 2015; 21(3), 153-159.

14. Roski J, Schmid LA, Lando HA. (). Long-term associations of helpful and harmful spousal behaviors with smoking cessation. Addic Behav, 1996; 21(2), 173-185.

15. Mermelstein R, Lichtenstein E, Mclyntre K. Partner support and relapse in smoking cessation programs.J Consul Clin Phsyc, 1983; 51,456-466.

16. Park EW, Schultz JK, Tudiver F, Campbell T, Becker L. Enhancing partner support to improve smoking cessation. The Cochrane Database Syst Rev, 2004;(3):CD002928.2.

17. Park EW, Tudiver FG, Campbell T. Enhancing partner support to improve smoking cessation. Cochrane Database Syst Rev. 2012; 11;(7):CD002928.
18. Stead LF, Perera R, Bullen C, et al. Nicotine replacement therapy for smoking cessation. Cochrane Database SystRev 2012;11:CD000146.23152200.

19. Cahill K, Stead LF, Lancaster T. Nicotine receptor partial agonists for smoking cessation. Cochrane Database Syst Rev 2012;4:CD006103.22513936.

20. Hughes JR, Stead LF, Hartmann-Boyce J, Cahill K, Lancaster T. Antidepressants for smoking cessation. Cochrane Database Syst Rev 2014;1:CD000031.24402784.

21. Bart J, Critchley JA, Bengel J. Psychosocial interventions for smoking cessation in patients with coronary hearth disease. Cochrane Database Syst Rev 2008; 1: CD006886.

22. Stapleton J. Cigarette smoking prevalence, cessation and relapse. Stat Methods Med Res 1998; $\quad 7$ : 187-203. doi:10.1191/096228098671391775.9654641.

23. Memon A et al. What factors are important in smoking cessation and relapse in women from deprived communities? A qualitative study in southeast England. Public Health, 2016;134:39-45.

24. Aubin $\mathrm{HJ}$ et al. The French onservtional cohort of usual smokers (FOCUS) cohort: French smokers perceptions and attidues towards smoking cessation. BMC Public Health 2010;26:10:100.

25. Solberg LI et al. Smoking and cessation behaviors among young adults of various educational backgrounds. Am J Public Health 2007;97(8):1421-1426.

26. Villanti AC et al. Reasons to quit and barriers to quitting smoking in US yound adults. Family Practice 2016; 33 (2):133-139 